\title{
PENGARUH KEBIJAKAN PASCA BAYAR BIAYA PEMERIKSAAN INSTELASI LISTRIK TEGANGAN RENDAH TERHADAP PIUTANG USAHA TAK TERTAGI DI PT.PPILN SULAWESI TENGGARA
}

\author{
Hairuddin Bugis ${ }^{1}$; Juwita ${ }^{2}$ \\ ${ }^{12}$ Program Studi Manajemen, Fakultas Ekonomi dan Bisnis Islam Universitas Muhammadiyah \\ Kendari \\ e-mail: *hairuddin.bugis@umkendari.ac.id, juwita@umkendari.ac.id
}

\begin{abstract}
ABSTRAK: Pengaruh kebijakan biaya pasca bayar inspeksi instalasi tegangan rendah terhadap piutang tak tertagih di PT.PPILN Sulawesi Tenggara. Penelitian ini bertujuan untuk menganalisis pengaruh kebijakan biaya pasca bayar inspeksi instalasi tegangan rendah $(\mathrm{X})$ terhadap piutang tak tertagih di PT.PPILN Sulawesi Tenggara (Y). Populasi dan sampel adalah 30 karyawan dan pengurus PT.PPILN Sulawesi Tenggara. Data yang dikumpulkan adalah data primer yang meliputi persepsi seluruh responden. Pengumpulan data dilakukan dengan menggunakan kuesioner. Kemudian data dianalisis menggunakan SPSS versi23. Uji regresi sederhana antara variabel $X$ dan variabel $Y$ menyimpulkan bahwa $\mathrm{H} 1$ diterima dan $\mathrm{HO}$ ditolak karena signifikansi yang tinggi dengan nilai koefisien 0,000 . Hasil penelitian juga menunjukkan bahwa koefisien determinasi $R$ square (R2) sebesar 0,114. Artinya, piutang tak tertagih tersebut terkena dampak kebijakan pasca bayar sebesar $11,4 \%$. Sedangkan $88,6 \%$ dipengaruhi oleh variabel lain yang tidak diketahui.
\end{abstract}

Kata Kunci: akun pascabayar; tidak tertagih.

Abstract: The effect of post-paid expense policy of low voltage installation inspection on uncollectible account at PT. PPILN South East Sulawesi. This study is aim at analyzing the effect of post-paid expense policy of low voltage installation inspection $(X)$ on uncollectible account at PT.PPILN South East Sulawesi (Y). The population and sample was 30 employees and the managing board members at PT. PPILN South East Sulawesi. The data collected was primary data which included the perception of all respondents. The data was gathered using questionnaire. Then the data was analyzed using SPSS version23. The simple regression test between variable $X$ and Variable $Y$ concludes that $\mathrm{H} 1$ is accepted and $\mathrm{HO}$ is rejected due to a high significance with coefficient value 0.000 . The result also reveals that the coefficient determination $R$ square $\left(R^{2}\right)$ is 0.114 . It means that uncollectible account is affected as much as $11.4 \%$ by the post-paid policy. Meanwhile $88.6 \%$ is affected by other unknown variables.

Keywords: post-paid; uncollectible account.

\section{PENDAHULUAN}

Perkembangan dunia bisnis pada era globalisasi menuntut kinerja yang sempurna dari setiap proses yang dijalankan oleh perusahaan. Pemasaran tidak lagi dipandang sebagai bagian yang terpisah dari organisasi yang hanya berperan sebagai proses penjualan produk. Perkembangan konsep pemasaran sendiri tidak terlepas dari 
fungsi-fungsi organisasi yang lain dan pada akhirnya mempunyai tujuan untuk memuaskan pelanggan. Pemasaran yang tidak efektif (ineffective marketing) dapat membahayakan bisnis karena dapat berakibat pada konsumen yang tidak puas. Pemasaran yang efektif (effective marketing) justru berakibat sebaliknya yaitu menciptakan nilai atau utilitas. Menciptakan nilai dan kepuasan pelanggan adalah inti pemikiran pemasaran modern. Tujuan kegiatan pemasaran adalah menarik pelanggan baru dengan menjanjikan nilai yang tepat dan mempertahankan pelanggan saat ini dengan memenuhi harapannya sehingga dapat menciptakan tingkat kepuasan.

Salah satu kegiatan pemasaran adalah melakukan transaksi terdiri dari transaksi penjualan barang atau jasa, baik secara kredit atau tunai. Dalam transaksi penjualan kredit, jika order dari pelanggan telah dipenuhi dengan pengiriman barang atau penyerahan jasa, untuk jangka waktu tertentu perusahaan memiliki piutang kepada pelanggannya. Kegiatan penjualan kredit ini ditangani oleh perusahaan melalui sistem penjualan kredit. Dalam transaksi penjualan tunai, barang atau jasa baru diserahkan oleh perusahaan kepada pembeli jika perusahaan telah menerima kas dari pembeli. Kegiatan penjualan secara tunai ini ditangani oleh perusahaan melalui sistem penjualan tunai. Masalah yang umum yang dihadapi perusahaan ialah penagihan piutang yang telah jatu tempoh tidak selalu dapat diselesaikan seluruhnya. Jika keadaan ini terus berlangsung dalam jangka waktu yang lama maka modal perusahaan akan semakin kecil

PT PPILN (Perintis Perlindungan Instalasi Listrik Nasional) sebagai perusahaan yang bergerak dibidang sertifikasi instalasi listrik tegangan rendah milik konsumen /calon konsumen sebagaimana yang telah ditetapkan oleh Kementerian Energi dan Sumber Daya Mineral (ESDM) Nomor 484/20/DJL.4/2015 pada tanggal 10 Desember 2015 selaku salah satu lembaga inspeksi Listrik Tegangan Rendah (LTR). Tugas pokok PT PPILN antara lain: Melakukan pemeriksaan dan pengujian kesesuaian instalasi pemanfaatan tenaga listrik tegangan rendah terhadap Persyaratan Umum Instalasi Listrik, Menerbitkan Sertifikat Laik Operasi (SLO) dan Mensosialisasikan Undang-Undang No.30 Tahun 2009 Tentang Ketenagalistrikan dan Peraturan Pemerintah No.14 Tahun 2012 serta Peraturan Menteri ESDM No.10 Tahun 2016.

PT.PPILN Menerbitkan Sertifikat Laik Operasi (SLO) kepada para pelangganya dengan menetapkan biaya/harga pemeriksaan sesuai Keputusan Mentri ESDM Cq Dirjen ketenaga listrikan, berdasarkan besaran daya setiap meter pelanggan dengan harga yang bervariasi. Ketetapan ini lebih lanjut belaku seragam untuk semua lembaga inspeksi LTR yang berada di Sulawesi Tenggara termasuk PT.PPILN Sulawesi Tenggara. Sesuai dengan ketatapan derektur PT.PPIL PUSAT bahwa penerapan pembayaran biaya pemeriksaan tersebut diawal kegiatan pemeriksaan atau pembayaran harus dilakuakan para pelanggan sebelum diadakan inpeksi terhadap Instelasi para pelanggan, akan tetapi hal ini sulit diterapkan di PT.PPILN Sulawesi Tenggara oleh karena persaingan antara LTR yang sudah ada dalam hal merebut calon pelanggan. Oleh karena itu, manajemen PT.PPILN Sulawesi Tenggara menempuh kebijakan atau strategi penjualan kredit yakni pembayaran biaya intelasi baik instelasi pasang baru ataupun tambah daya dilakukan setelah penerbitan SLO sebagai syarat kelayakan beroperasinya jaringan listrik mereka.

Kebijakan penjualan kerdit oleh Manajemen PT.PPILN tersebut berdampak posotif yaitu dapat menarik para pelanggan sebanyak mungkin untuk menjadi konsumen PT.PPILN Sulawesi Tenggara, akan tetapi di lain pihak kebijakan tersebut menyebabkan 
kekayaan PT. PPILN tercatat sebagai piutang yang semakin bertambah dari waktu ke waktu, serta sulit untuk ditagih tepat waktu sesuai waktu yang disepakati.

Dilain pihak Kebijakan pasca bayar juga berakibat berubah arus penerimaan biaya pemeriksaan, semula masyarakat langsung melakukan pembayar kepada bendahara PT.PPILN Sulawesi tenggara, namun seiring kebijakan tersebut seluruh pembayaran biaya pemeriksaan tidak lagsung ke bendahara akan tetapi pembayaran dari masyarakat terlebih dahulu melalui beberapa titik kemudian terakhir ke bendahara. Arus penerimaan biaya pemeriksaan yang terjadi di PPILN SULTRA dapat digambarkan seperti berikut ini:

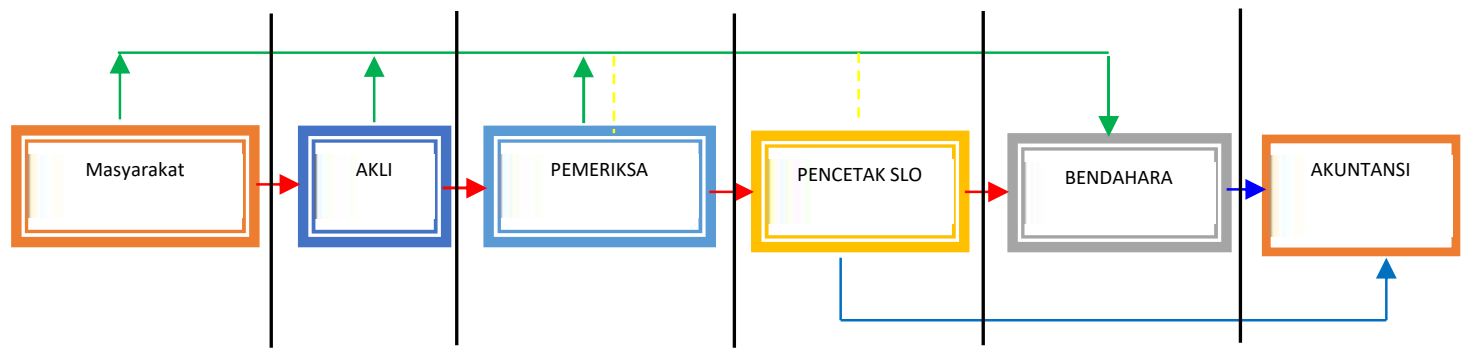

Gambar 1. Alur Bayar Biaya Pemeriksaan

\section{KETERANGAN}

Sangat banyak (bayar Koletif maupun sendiri-sendiri dan terjadi piutang)

Kadang-kadang dan selalu 100\% lunas

Dikoordinasikan

Data penerimaan biaya pemeriksaan ke bagian akuntansi.

Disamping itu, berdasarkan hasil pengamatan lapangan bahwa tenaga pemeriksa mengalami tingkat tourn over yang tinggi setiap tahun. Hal ini sesuai data ketanagakerjaan PT.PPILN bahwa setiap tahun terjadi pemutusan hubungan kerja karyawan lama ataupun merekrut karyawan baru. Pada hal karyawan pemeriksa adalah pihak yang lebih mengetahui dimana keberadaan piutang tak tertagi itu, hal ini sebagai akibat para pemeriksa diperbolehkan untuk menerima biaya tersebut dari masyarakat, baik biaya yang dibayar oleh pemilik instelasi ataupun dari para kontraktor yang bergabung didalam AKLI. Arus pembayaran biaya dapat diamati di gambar 1 . Berikut posisi piutang tak tertagi tahun 2012 - 2017, PT.PPILN Wilayah Sulawesi Tenggara.

Tabel 1.Piutang Yang tak Tertagih 2012-2017

\begin{tabular}{|c|c|c|c|c|c|c|c|c|}
\hline \multirow{2}{*}{ No } & \multirow{2}{*}{ KETERANGAN } & \multicolumn{6}{|c|}{ TAHUN } & \multirow[t]{2}{*}{ JUMLAH } \\
\hline & & 2012 & 2013 & 2014 & 2015 & 2016 & 2017 & \\
\hline 1 & $\begin{array}{l}\text { Tercetak } \\
(\mathrm{SLO})\end{array}$ & 1015 & 930 & 842 & 846 & 1200 & 933 & 5766 \\
\hline 2 & $\begin{array}{l}\text { Total Biaya } \\
\text { (Rp) }\end{array}$ & 71,050,000.- & $65,100,000 .-$ & $58,940,000,-$ & 59,240,000.- & 72,000,000.- & $56,000,000 .-$ & $382,330.000,-$ \\
\hline 3 & $\begin{array}{l}\text { Terbayar Pada } \\
\text { Bendahara } \\
\text { (Rp) } \\
\end{array}$ & 0 & 0 & 0 & 0 & 0 & 0 & 0 \\
\hline 4 & $\begin{array}{l}\text { Belum } \\
\text { Terbayar (Rp) }\end{array}$ & 71,050,000.- & $65,100,000 .-$ & $58,940,000,-$ & $59,240,000 .-$ & $72,000,000 .-$ & $56,000,000 .-$ & $382,330.000$ \\
\hline
\end{tabular}

Sumber : Data diolah dari Laporan Keuangan Time Series PT. PPILN Sultra 2012 -2017 


\section{METODE PENELITIAN}

Penelitian ini menggunakan pendekatan kuantitatif, metode yang digunakan adalah metode survey. Penggunaan metode ini dimaksudkan untuk mendeskripsikan sejumlah masalah yang berkaitan dengan kebijakan Manajemen PT.PPILN Sulawesi Tenggara Terkait Psaca Bayar yang berakibat kepada Piutang Tak Tertagih. Metode survey lebih cepat digunakan untuk menguraikan masalah-masalah yang hangat dan aktual atau peristiwa yang terjadi pada masa yang akan datang (Furchan:1982) dalan (Sugioni:2010)

Pelaksanaan penelitian ini berlangsung di Kantor PT, PPILN Sulawesi Tenggara dengan obyek penelitian adalah Para Karyawan dan staf di PT.PPILN Sulawesi Tenggara. Pengambilan sampel harus dilakukan sedemikian rupa sehingga diperoleh sampel yang benar-benar dapat menggambarkan keadaan populasi yang sesungguhnya atau dapat juga dikatakan sampel haruslah representatif (mewakili) populasi. Menurut Nasution (1987:115) memilih suatu jumlah tertentu untuk diselidiki dari keseluruhan populasi disebut sampling. Populasi dalam penelitian ini berjumlah 30 orang, mereka terdiri dari keseluruhan jajaran manajemen, staff admininstrasi dan keuangan, karyawan lapangan, dan pengurus di rayon-rayon yang ada di Sulawesi tenggara. Sampel dalam penelitian ini adalah keseluruhan populasi yang berjumlah 30 orang.

Pengumpulan data subyektif dalam penelitian ini dengan cara Kuesioner, cara ini digunakan untuk menjaring jawaban tertulis tentang pertanyaan maupun pernyataan yang terkait indikator-indikator dari variabel penelitian ini. Secara operasional penelitian ini bertujuan untuk mengetahui atau memperoleh informasi tentang piutang tak tertagi yang disebabkan oleh kebijakan Pasca Bayar yang ditempuh oleh Manajemen. Secara rinci variabel terikat $(\mathrm{Y})$ adalah Piutang Tak Tertagi, sebagai variabel terikat, sementara variable bebas $(\mathrm{X})$ adalah Kebijakan Pasca Bayar Biaya Pemeriksaan Instelasi Listrik Tegangan Rendah.

Pengukuran variabel penelitian dilakukan dengan menetapkan indikator dan skala likert untuk masing-masing variabel. Penggunaan skala likert (1-5. Setelah menghimpun data dari responden maka data tersebut ditabulasi ke dalam suatu tabel skor jawaban dimana data disusun sesuai urutan pertanyaan atau pernyataan ke bawah dengan sisitim skor jawaban daripada setiap responden terhadap suatu pertanyaan atau pernyataan, kemudian akumulasi jawaban terhadap suatu pertanyaan atau pernyataan tersebut akan di pindahkan ke tabel rekap (tabel XY) (Sugiono:2008). Adapun indikator dan pengukuran skala likert yang dilakukan adalah sebagai berikut :

1. Untuk pilihan jawaban: sangat setuju/selalu/sangat baik, diberi skor 5

2. Untuk pilihan jawaban: setuju/sering/baik, diberi skor 4

3. Untuk pilihan jawaban: ragu-ragu/kadang-kadang/hampir baik, diberi skor 3

4. Untuk pilihan jawaban: tidak setuju/hampir tidak pernah/tidak baik, diberi skor 2

5. Untuk pilihan jawaban: sangat tidak setuju/tidak pernah/sangat tidak baik, diberi skor 1

Kelima skala likert untuk pernyataan posotif dan memiliki nilai yang berkebalikan untuk pernyataan yang negatif. Sebelum menganalisis lebih jauh data yang akan dijaring maka perlu dilakukan uji instrumen dengan asumsi: Instrumen falid berarati instrument tersebut dapat dipergunakan untuk mengukur apa yang seharusnya diukur, ini berarti 
hasil penelitian valid jika terdapat kesamaan data yang terkumpul dengan data yang sesungguhnya terjadi pada obyek yang diteliti. Selanjutnya hasil penelitian reabel bila terdapat kesamaan data dalam waktu yang berbeda (Sugiono:2010).

\section{HASIL PENELITIAN DAN PEMBAHASAN Kajian Teori}

\section{Strategi Pemasaran}

Strategi pemasaran merupakan strategi untuk melayani pasar atau segmen pasar yang dijadikan target oleh seorang pengusaha. Oleh karena itu, strategi pemasaran merupakan kombinasi dari bauran pemasaran yang akan ditetapkan oleh pengusaha untuk melayani pasarnya. Strategi pemasaran harus menggambarkan pasar sasaran dan posisi perusahaan di dalamnya, termasuk informasi mengenai pasar, kinerja produk, persaingan serta distribusi. Strategi pemasaran (marketing strategy) adalah suatu cara yang digunakan untuk membantu kita membuat dan menjual barang dan jasa yang sesuai dengan kondisi perusahaan dan pasar target atau selerah konsumen yang dituju. (Suharyadi dkk:2007). Memilih metode yang tepat sebagai startegi dalam memindahkan barang ataupun jasa kepada pelanggan adalah suatu kondisi alternatif yang dihadapai para pemasar dan penjual sesuai dengan garis kebijakan pemasaran yang ditetapkan menajemen suatu entitas bisnis. Hal ini lebih kepada bagaimana merebut pangsa pasar yang tinggi daripada pangsa pasar yang dimiliki lawan atau pesaing.

Dalam lingkungan yang persaingannya sengit, tenaga pemasaran harus meyakinkan pembeli bahwa mereka harus membeli produk mereka, bukan membeli produk yang dijual penjual lain. Karena pembeli konsumen dan pembeli komersial memiliki sumberdaya yang terbesar yang harus yang dikeluarkan, setiap dolar untuk membeli suatu produk tidak lagi dapat digunakan untuk pembelian lain. Dengan demikian, setiap program pemasaran mecari cara agar produknya terlihat paling menarik (Ricky dan Ronald:2006).

\section{Penjualan Kredit}

Penjualan kredit merupakan kegiatan yang dilakukan untuk menyampaikan barang kepada mereka yang memerlukan dengan jalan tidak segera meminta kontraprestasi pada waktu penjualan dilakukan. Pengertian Penjualan Menurut Haryono (2003: 327) bahwa penjualan kredit adalah penjualan yang dilakukan bilamana pembayarannya baru diterima beberapa waktu kemudian. Selanjutnya, Mulyadi (1997: 204) menyatakan bahwa dalam transaksi penjualan kredit. Jika order dari pelanggan telah dipenuhi dengan pengiriman barang atau penyerahan jasa, untuk jangka waktu tertentu perusahaan memiliki piutang kepada pelanggannya. Sedangkan pengertian lain dari penjualan kredit adalah penjualan kredit menimbulkan tagihan kepada pelanggan sebesar harga jualn bersih setelah trade discount. Penjualan kredit ini dilakukan oleh perusahan dengan maksud untuk meningkatkan volume penjualan selain digunakan untuk mengimbangi pesaing (Rahmini hadi:2011).

Piutang Usaha 
Setiap pemimpin perusahaan selalu menginginkan penjualan barang dagangannya dibayar secara tunai. Namun, dilain phak, penjualan secara kredit justru akan memberi peluang untuk perluasan pasar sehingga dapat menambah laba usaha, meski hal ini juga bukan tanpa risiko. Piutang adalah tagihan kepada individu atau perusahaan lain yang akan diterima dalam bentuk kas. Pada umumnya piutang diklasifikasi menjadi piutang usaha (dagang), piutang wesel, dan piutang lain-lain. (Rudianto:2012)

Piutang usaha yaitu piutang yang timbul dari penjualan barang atau jasa yang dihasilkan perusahaan. Dalam kegiatan normal perusahaaan, piutang usaha biasanya akan dilunasi dalam tempo kurang dari satu tahun, sehingga piutang usaha dikelompokkan kedalam kelompok aset lancer, dengan demikian penagihan piutang perlu mendapat perhatian dan penangan serius agar resiko yang mungkin timbul dpat dihindarkan sekecil mungkin. Dalam hal ini, pimpinan seharusnya juga turut aktif mengelola penagihan piutang agar tidak sampai menghambat operasi atau kegiatan perusahaan. (Rudianto:2012)

Sesuai dengan Standar Akuntansi Keuangan yang berlaku di Indonesia, piutang dicatat dan diakui sebesar jumlah bruto (nilai jatuh tempo) dikurangi dengan taksiran jumlah yang tidak akan diterima. Itu berarti piutang harus dicatat sebesar jumlah yang diharapkan akan dapat ditagih. Karena itu berkaitan dengan pengelolaan piutang, perusahaan harus membuat suatu cadangan piutang tidak tertagih yang merupakan taksiran jumlah piutang yang tidak akan dapat ditagih dalam periode tersebut.

\section{Piutang Tak Tertagih}

Pengertian piutang tak tertagih, menurut Keiso dan Weygand, adalah "kerugian pendapatan yang memerlukan melalui ayat-ayat pencatatan yang tepat di dalam perkiraan harta piutang dan penurunan yang berkaitan dalam laba dan ekuitas pemegang saham. (Donald E:2004)

Secara umum, suatu piutang diindikasikan sebagai piutang tak tertagih apabila telah jauh melewati tanggal jatuh temponya. Piutang yang telah ditentukan sebagai piutang tak tertagih merupakan suatu kerugian yang harus dicatat sebagai beban (expense), yaitu beban piutang tak tertagih (bad debt expese) dalam laporan laba rugi. Semua penghapusan ini harus dicatat dengan tepat dan teliti karena berhubungan langsung dengan laporan yang digunakan manajemen dalam mengambil keputusan. (Abdul Halim:2002)

Menurut Abdul, kredit macet atau piutang tak tertagih dapat disebabkan oleh beberapa faktor yaitu: Faktor Internal, yaitu faktor-faktor yang berasal dari pihak kreditur dan Faktor Eksternal, yaitu faktor-faktor yang berasal dari pihak debitur. (Abdul Halim:2002)

Hasil penelitian yang relevan dan dirujuk ke dalam suatu rancangan penelitian akan di amati dari beberapa aspek yakni nama Sipeneliti, Judul dan lokasi penelitian terkait, variable penelitan dan hipotesisnya, alat analisis serta hasil penelitian dan peluang variable yang akan diteliti berikutnya. Pada rancangan penelitian ini akan dibatasi sehingga unsure yang dirujuk adalah Nama peneliti, judul dan hasil penelitian yang relevan saja sementara aspek lain diabaikan. 
Muhammad Indra Lukman Hakim 2016, Penanganan Piutang Tak Tertagih Dalam Perspektif Ekonomi Islam (Studi Kasus di Toko Bangunan Sumber Makmur Pegandon Kendal). Hasil penelitian menunjukkan bahwa: (1) Untuk menangani piutang tak tertagih, toko bangunan Sumber Makmur Pegandon Kendal melakukan penagihan piutang tempo dengan: (a) Pemberitahuan hutang jatuh tempo melaui telepon, (b) Menghubungi kembali untuk memberitahukan tempo (c) Penagihan langsung ke rumah konsumen. Apabila belum berhasil, toko bangunan Sumber Makmur Pegandon Kendal melakukan penyelesaian dengan cara memberikan toleransi (rescheduling), musyawarah (reconditioning), pembebasan. (2) Penyelesaian piutang tak tertagih yang dilakukan di toko bangunan Sumber Makmur Pegandon Kendal secara ekonomi Islam sudah sesuai karena dalam penyelesaiannya mengedepankan unsur toleransi (tasamuh), musyawarah (shulhu), dan pembebasan (shulhu ibra'). Gap penelitian yang dapat dikemukakan disini adalah obyek yang berbeda dan pada penelitian diatas menyoroti penanganan atau penagihan piutang tak tertagih sementara pada penelitian ini akan menyoroti sisi kibijakan yang memunculkan penjualan secara kredit.

Arsyina Lutfi Arrum Sari, 2015. Analisis Faktor-Faktor Penyebab Piutang Tak Tertagih Pada PT.PELINDO III (Persero) Cabang Tanjung Emas Semarang. Hasil penelitian menunjukkan, faktor-faktor penyebab piutang tak tertagihada 2 yaitu faktor intern dan faktor ekstern. Untuk faktor intern sendiridi pengaruhi oleh pihak Pelabuhan dan pengguna jasa, sedangkan faktor ekstern disebabkan oleh kondisi yang tidak pernah diharapkan oleh pihak manapun. Gap penelitian yang dapat dikemukakan disini adalah obyek yang berbeda dan pada penelitian diatas sipeneliti mengkaji penyebab munculnya piutang tak tertagih sementara pada penelitian ini langsung menetapkan satu factor yakni kibijakan yang memunculkan penjualan secara kredit sebagai variable dalam penelitian ini.

Devianti 2012, Tinjauan Atas Analisis Piutang Usaha Pada Toyota Sales Operation (Auto 2000) Cabang Cibiru Bandung. Hasil perhitungan dan perbandingan analisis piutang usaha AUTO 2000 cabang Cibiru Bandung dengan menggunakan Rasio Receivable turnover di Tahun 2010 sampai dengan Tahun 2011 terjadi penurunan masing-masing 9 kali dan 8 kali, sedangkan Rasio Receivable collection Period di Tahun 2010 sampai dengan Tahun 2011 terjadi kenaikan masing-masing 39 Hari dan 43 Hari. Gap penelitian yang dapat dikemukakan disini adalah obyek yang berbeda dan pada penelitian diatas sipeneliti mengamati trend pitang usaha dengan menggunakan alat anasis keuangan di tahun 2010 sampai dengan Tahun 2011 sementara pada penelitian ini melihat pengaruh kebijakan Pasca Bayar yang berakibat piutang tak tertagih.

Mikky Fariana, Elfreda A Lau dan Adi Suros. 2012. Pengendalian Piutang Dagang Pada PT. Kokoh Inti Arebama Cabang Samarinda. Hasil kesimpulan, diketahui bahwa pengendalian piutang dagang telah efektif, $85 \%$ telah dilaksanakan dan telah memenuhi tahapan-tahapan sistem pengendalian piutang dagang, Gap penelitian yang dapat dikemukakan disini adalah obyek yang berbeda dan pada penelitian diatas sipeneliti menyoroti pengendalian piutang sementara pada penelitian ini melihat pengaruh kebijakan Pasca Bayar yang berakibat piutang tak tertagih.

Iryani, 2016. Analisis pengelolaan piutang usaha Robin Cell. Hasil penelitian menunjukkan bahwa dalam menilai resiko kredit, Robin Cell menerapkan $5 \mathrm{C}$ (capacity, character, capital, collateral,condition). Analisis kredit 5C bertujuan untuk memberikan 
gambaran bagi Robin Cell dalam memberikan piutang kepada debiturnya dalam melakukan pembayaran sesuai dengan waktu yang telah ditentukan. Gap penelitian yang dapat dikemukakan disini adalah obyek yang berbeda dan pada penelitian diatas sipeneliti menyoroti pengendalian piutang sementara pada penelitian ini melihat pengaruh kebijakan Pasca Bayar yang berakibat piutang tak tertagih.

Murni, 2009. Analisis Pemberian Kredit Dalam Menunjang Perkembangan Industri Kecil di Kota Makassar. Hasil penelitian menyimpulkan bahwa (1) Hubungan antara pemberian kredit terhadap industri kecil sangat besar dan positif, hal ini dilihat pada hasil perhitungan koefisien korelasi yang mencapai 0,96. (2) sesuai hasil perhitungan koefisien determinasi sangat besar yaitu mencapai 0,9314 atau 93,14\% dan $6,86 \%$ dipengaruhi oleh variabel lain yang tidak diketahui. Gap penelitian yang dapat dikemukakan disini adalah obyek yang berbeda dan pada penelitian diatas sipeneliti menguji hepotesis tentang hubungan variable pemberian kterdit terhadap industry kesil sementara pada penelitian ini melihat pengaruh kebijakan Pasca Bayar terhadap piutang tak tertagih.

Neneng Salmiah, Satria Tri Nanda. 2016 Analisis Penilaian Kredit Pada Bpr Indo Mitra Mega Kapital Dan Bpr Payung Negeri Bestari di Kota Pekanbaru. penelitian ini bertujuan untuk menganalisis perbedaan penilaian kredit (prinsip 5C) antara BPR Indo Mitra Mega Kapital dengan BPR Payung Negeri Bestari yang dapat memberikan jawaban terhadap terjadinya perbedaan KAP yang sangat jauh tersebut. Objek penelitian ini adalah penilaian kredit dengan menggunakan analisis $5 \mathrm{C}$ yang terdiri dari Character, Capacity, Capital, Colleteral dan Condition. Jenis penelitian ini adalah deskriptif dengan pendekatan gabungan antara metode kuantitatif dan kualitatif. Metode analisa data dengan melakukan uji statistik deskriptif. Hasil penelitian menunjukkan bahwa terdapat perbedaan penilaian kredit antara BPR Indo Mitra Mega Kapital dengan BPR Payung Negeri Bestari yaitu pada variabel capacity terutama pada indikator 4 dan 5. Dari hasil statistik variabel capacity item pernyataan keempat menunjukkan bahwa BPR Indo Mitra Mega kapital hanya menganggap penting analis kredit bersama AO wajib survai untuk melihat usaha yang sedang dijalankan oleh calon debitur. Gap penelitian yang dapat dikemukakan disini adalah obyek yang berbeda dan pada penelitian diatas sipeneliti menyoroti penerarapan Metode $5 \mathrm{C}$ terhadap calon kreditur sementara pada penelitian ini melihat pengaruh kebijakan Pasca Bayar terhadap piutang tak tertagih.

PT PPILN (Perintis Perlindungan Instalasi Listrik Nasional) sebagai perusahaan yang bergerak dibidang sertifikasi instalasi listrik tegangan rendah milik konsumen /calon konsumen sebagaimana, yang telah ditetapkan oleh Kementerian Energi dan Sumber Daya Mineral (ESDM) Nomor 484/20/DJL.4/2015 pada tanggal 10 Desember 2015. Alamat Kantor Pusat PT PPILN; Jl.Pemuda No. 55 Demak Jawa Tengah.Telp (0291) 6905519, 686219. Fax (0291) 6904219. Email: ppiln_pusat@yahoo.com. PT.PPILN mempunyai kegiatan antara lain: 1)Melakukan pemeriksaan dan pengujian kesesuaian instalasi pemanfaatan tenaga listrik tegangan rendah terhadap Persyaratan Umum Instalasi Listrik; 2)Menerbitkan Sertifikat Laik Operasi (SLO).3)Mensosialisasikan Undang-Undang No. 30 Tahun 2009 Tentang Ketenagalistrikan dan Peraturan Pemerintah No. 14 Tahun 2012 serta Peraturan Menteri ESDM No. 10 Tahun 2016. 
Biaya Pemeriksaan Instalasi Daya 450 VA - 197.000 VA

Berikut adalah rincian biaya pemeriksaan keamanan instalasi arus listrik. Biaya dibawah ini sudah termasuk PPN $10 \%$.

Tabel 2. Harga Biaya Pemeriksaan Intelasi Tegangan Rendah

\begin{tabular}{|c|c|c|c|c|c|c|c|}
\hline No & Daya & Per VA & $\begin{array}{c}\text { Biaya } \\
\text { Pemeriksaan } \\
\end{array}$ & No & Daya & Per VA & Biaya Pemeriksaan \\
\hline 1 & 450 & & Rp. 40.000,- & 13 & 16500 & \multirow{2}{*}{ Rp. 25,- } & Rp. 412.500,- \\
\hline 2 & 900 & & Rp. 60.000,- & 14 & 23000 & & Rp. 575.000,- \\
\hline 3 & 1300 & & Rp. 95.000,- & 15 & 33000 & \multirow{3}{*}{ Rp. 20,- } & Rp. 660.000,- \\
\hline 4 & 2200 & & Rp. 110.000,- & 16 & 41500 & & Rp. 830.000,- \\
\hline 5 & 3500 & \multirow{5}{*}{ Rp. 30,- } & Rp. 105.000,- & 17 & 53000 & & Rp. 1.060.000,- \\
\hline 6 & 4400 & & Rp. 132.000,- & 18 & 66000 & & Rp. 1.320.000,- \\
\hline 7 & 5500 & & Rp. 165.000,- & 19 & 82500 & \multirow{5}{*}{ Rp. 15} & Rp. 1.237.500,- \\
\hline 8 & 6600 & & Rp. 198.000,- & 20 & 105000 & & Rp. 1.575.000,- \\
\hline 9 & 7700 & & Rp. 231.000,- & 21 & 131000 & & Rp. 1.965.000,- \\
\hline 10 & 10600 & \multirow{3}{*}{ Rp. 25,- } & Rp. 265.000,- & 22 & 147000 & & Rp. 2.205.000,- \\
\hline 11 & 11000 & & Rp. 275.000,- & 23 & 197000 & & Rp. 2.955.000,- \\
\hline 12 & 13200 & & Rp. 330.000,- & & & & \\
\hline
\end{tabular}

Sertifikat Laik Operasi (SLO) merupakan Solusi Keselamatan Instalasi Listrik yang dikeluarkan oleh PT. PPILN setelah melakukan pemeriksaan. Dengan adanya sertifikat dari PT. PPILN berarti instalasi anda telah terpasang telah sesuai dengan SNI dan PUIL, sehingga mengurangi resiko terjadinya kebakaran akibat dari hubungan singkat arus listrik.

Sertifikat Laik Operasi (SLO)

Sertifikat Laik Operasi (SLO) adalah sertifikat yang dikeluarkan oleh perusahaan sebagaimana yang telah diamanatkan oleh Menteri ESDM melalui surat ketetapan PT PPILN mengeluarkan Sertifikat Laik Operasi yang dicetak secara Online menggunakan SI OMSIL dan dapat diperiksa status sertifikasinya secara online. Lebih lanjut mengenai SIOMSIL dapat diketahui. PT PPILN mengeluarkan Sertifikat Laik Operasi setelah melakukan pemeriksaan dan pengujian terhadap instalasi listrik. Contoh Sertifikat Laik Operasi yang diterbitkan PT PPILN :

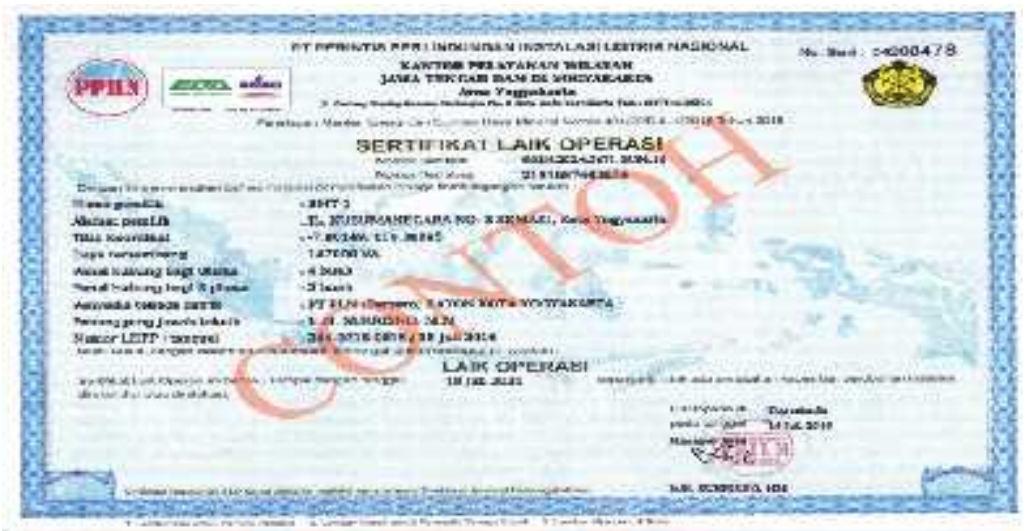

Gambar 2. Sertifikat Laik Operasi 
Uji Validitas dan Reliabilitas

Uji validitas $Y$

\section{Tabel 3. Correlations}

\begin{tabular}{|c|c|c|c|c|c|c|c|c|}
\hline & & Item 1 & Item 2 & Item 3 & Item 4 & Item 5 & Item 6 & $Y$ \\
\hline \multirow[t]{3}{*}{ Item 1} & $\begin{array}{l}\text { Pearson } \\
\text { Correlation }\end{array}$ & 1 & .176 & .115 & .224 & -.036 & .036 & $.361^{*}$ \\
\hline & Sig. (2-tailed) & & .221 & .428 & .117 & .803 & .803 & .010 \\
\hline & $\mathrm{N}$ & 30 & 30 & 30 & 30 & 30 & 30 & 30 \\
\hline \multirow[t]{3}{*}{ Item 2} & $\begin{array}{l}\text { Pearson } \\
\text { Correlation }\end{array}$ & .176 & 1 & $.319^{*}$ & $.339^{*}$ & .240 & .224 & $.574^{* *}$ \\
\hline & Sig. (2-tailed) & .221 & & .024 & .016 & .094 & .118 & .000 \\
\hline & $\mathrm{N}$ & 30 & 30 & 30 & 30 & 30 & 30 & 30 \\
\hline \multirow[t]{3}{*}{ Item 3} & $\begin{array}{l}\text { Pearson } \\
\text { Correlation }\end{array}$ & .115 & $.319^{*}$ & 1 & .225 & $.478^{* *}$ & $.605^{* *}$ & $.761^{* *}$ \\
\hline & Sig. (2-tailed) & .428 & .024 & & .117 & .000 & .000 & .000 \\
\hline & $\mathrm{N}$ & 30 & 30 & 30 & 30 & 30 & 30 & 30 \\
\hline \multirow[t]{3}{*}{ Item 4} & $\begin{array}{l}\text { Pearson } \\
\text { Correlation }\end{array}$ & .224 & $.339^{*}$ & .225 & 1 & $.488^{* *}$ & .228 & $.642^{* *}$ \\
\hline & Sig. (2-tailed) & .117 & .016 & .117 & & .000 & .111 & .000 \\
\hline & $\mathrm{N}$ & 30 & 30 & 30 & 30 & 30 & 30 & 30 \\
\hline \multirow[t]{3}{*}{ Item 5} & $\begin{array}{l}\text { Pearson } \\
\text { Correlation }\end{array}$ & -.036 & .240 & $.478^{* *}$ & $.488^{* *}$ & 1 & $.435^{* *}$ & $.726^{* *}$ \\
\hline & Sig. (2-tailed) & .803 & .094 & .000 & .000 & & .002 & .000 \\
\hline & $\mathrm{N}$ & 30 & 30 & 30 & 30 & 30 & 30 & 30 \\
\hline \multirow[t]{4}{*}{ Item 6} & $\begin{array}{l}\text { Pearson } \\
\text { Correlation }\end{array}$ & .036 & .224 & $.605^{* *}$ & .228 & $.435^{* *}$ & 1 & $.692^{* *}$ \\
\hline & Sig. (2-tailed) & .803 & .118 & .000 & .111 & .002 & & .000 \\
\hline & $\mathrm{N}$ & 30 & 30 & 30 & 30 & 30 & 30 & 30 \\
\hline & $\begin{array}{l}\text { Pearson } \\
\text { Correlation }\end{array}$ & $.361^{*}$ & $.574^{* *}$ & $.761^{* *}$ & $.642^{* *}$ & $.726^{* *}$ & $.692^{* *}$ & 1 \\
\hline \multirow[t]{2}{*}{$Y$} & Sig. (2-tailed) & .010 & .000 & .000 & .000 & .000 & .000 & \\
\hline & $\mathrm{N}$ & 30 & 30 & 30 & 30 & 30 & 30 & 30 \\
\hline
\end{tabular}

*. Correlation is significant at the 0.05 level ${ }^{* *}$. Correlation is significant at the 0.01 (2-tailed). level (2-tailed).

Berdasarkan output diatas terlihat bahwa semua nilai item personal corelasi $Y$ sudah berada diatas 0,3 dan nilai signifikan $Y$ lebih kecil dari $\alpha(0,05)$, yang artinya semua data item pertanyaan untuk dimensi $Y$ yakni variable piutang tak tertagi sudah valid. 
Uji Reliabilitas $Y$

\begin{tabular}{c|c}
\hline \multicolumn{2}{c}{ Tabel 4. Reliability Statistics } \\
\hline Cronbach's Alpha & N of Items \\
\hline .701 & 6 \\
\hline
\end{tabular}

Berdasarkan output di atas terlihat bahwa nilai cronbach alpha 0,701 $>0,6$. Yang artinya data kuisioner atas variable piutang tak tertagih sudah reliable.

Uji Validitas $X$

Tabel 5. Correlations

\begin{tabular}{|c|c|c|c|c|c|c|c|c|}
\hline & & Item 1 & Item 2 & Item 3 & Item 4 & Item 5 & Item 6 & $x$ \\
\hline \multirow{3}{*}{ Item 1} & Pearson Correlation & 1 & -.032 & -.032 & .072 & .054 & .168 & $.314^{*}$ \\
\hline & Sig. (2-tailed) & & .828 & .826 & .621 & .712 & .243 & .026 \\
\hline & $\mathrm{N}$ & 30 & 30 & 30 & 30 & 30 & 30 & 30 \\
\hline \multirow{3}{*}{ Item 2} & Pearson Correlation & -.032 & 1 & $.560^{* *}$ & $.417^{* *}$ & $.709^{* *}$ & $.680^{* *}$ & $.771^{* *}$ \\
\hline & Sig. (2-tailed) & .828 & & .000 & .003 & .000 & .000 & .000 \\
\hline & $\mathrm{N}$ & 30 & 30 & 30 & 30 & 30 & 30 & 30 \\
\hline \multirow{3}{*}{ Item 3} & Pearson Correlation & -.032 & $.560^{* *}$ & 1 & $.441^{* *}$ & $.652^{* *}$ & $.394^{* *}$ & $.723^{* *}$ \\
\hline & Sig. (2-tailed) & .826 & .000 & & .001 & .000 & .005 & .000 \\
\hline & $\mathrm{N}$ & 30 & 30 & 30 & 30 & 30 & 30 & 30 \\
\hline \multirow{3}{*}{ Item 4} & Pearson Correlation & .072 & $.417^{* *}$ & $.441^{* *}$ & 1 & $.327^{*}$ & $.642^{* *}$ & $.730^{* *}$ \\
\hline & Sig. (2-tailed) & .621 & .003 & .001 & & .020 & .000 & .000 \\
\hline & $\mathrm{N}$ & 30 & 30 & 30 & 30 & 30 & 30 & 30 \\
\hline \multirow{3}{*}{ Item 5} & Pearson Correlation & .054 & $.709^{* *}$ & $.652^{* *}$ & $.327^{*}$ & 1 & $.518^{* *}$ & $.790^{* *}$ \\
\hline & Sig. (2-tailed) & .712 & .000 & .000 & .020 & & .000 & .000 \\
\hline & $\mathrm{N}$ & 30 & 30 & 30 & 30 & 30 & 30 & 30 \\
\hline \multirow{3}{*}{ Item 6} & Pearson Correlation & .168 & $.680^{* *}$ & $.394^{* *}$ & $.642^{* *}$ & $.518^{* *}$ & 1 & $.799^{* *}$ \\
\hline & Sig. (2-tailed) & .243 & .000 & .005 & .000 & .000 & & .000 \\
\hline & $\mathrm{N}$ & 30 & 30 & 30 & 30 & 30 & 30 & 30 \\
\hline \multirow{3}{*}{$x$} & Pearson Correlation & $.314^{*}$ & $.771^{* *}$ & $.723^{* *}$ & $.730^{* *}$ & $.790^{* *}$ & $.799^{* *}$ & 1 \\
\hline & Sig. (2-tailed) & .026 & .000 & .000 & .000 & .000 & .000 & \\
\hline & $\mathrm{N}$ & 30 & 30 & 30 & 30 & 30 & 30 & 30 \\
\hline \multicolumn{4}{|c|}{$\begin{array}{l}\text { *. Correlation is significant at the } 0.05 \text { level ( } 2 \text { - } \\
\text { tailed). }\end{array}$} & \multicolumn{5}{|c|}{$\begin{array}{l}\text { **. Correlation is significant at the } 0.01 \text { level ( } 2 \text { - } \\
\text { tailed). }\end{array}$} \\
\hline
\end{tabular}

Berdasarkan output diatas terlihat bahwa semua nilai item personal corelasi $\mathrm{X}$ sudah berada di atas 0,3 dan nilai signifikan $Y$ lebih kecil dari $\alpha(0,05)$, yang artinya semua data item pertanyaan untuk dimensi kebijakan pasca bayar $(X)$ sudah valid. 
Uji Reliabilitas $X$

\begin{tabular}{c|c}
\hline \multicolumn{2}{c}{ Tabel 6. Reliability Statistics } \\
\hline $\begin{array}{c}\text { Cronbach's } \\
\text { Alpha }\end{array}$ & N of Items \\
\hline .747 & 6 \\
\hline
\end{tabular}

Berdasrkan output di atas terlihat bahwa nilai cronbach alpha 0,747>0,6. Yang artinya data kuisioner tentang Kebjikan pasca bayar sudah reliable.

Uji Asumsi Klasik

Uji Normalitas

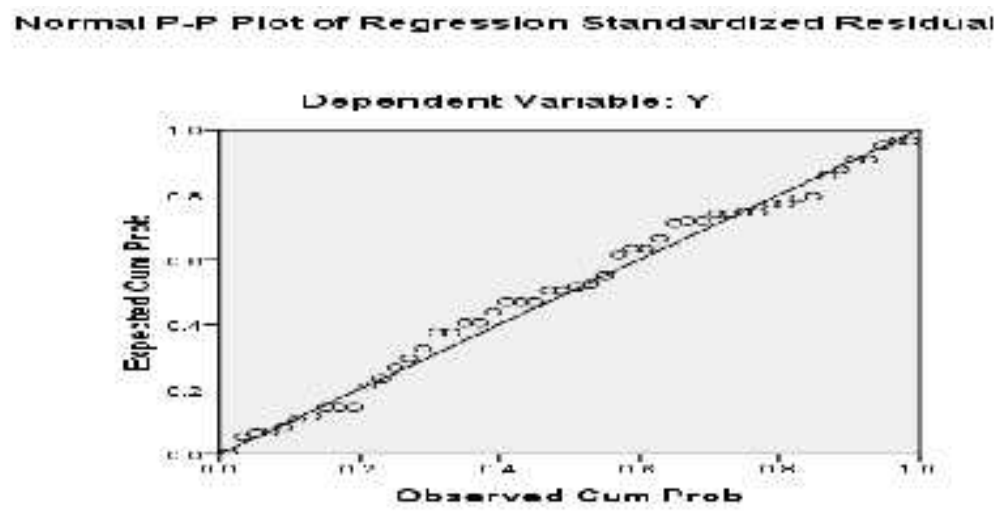

Gambar 3. Uji Normalitas

Berdasarkan output diatas, menjelaskan bahwa titik data yang ada mengikuti garis diagonal dari titik nol dan tidak melebar terlalu jauh, maka dapat disimpulkan data tentang kebijakan pasca bayar dan data tentang piutang tak tertagih berdistribusi normal.

Analisis Regrasi.

Pada penelitian ini hipotesis statistik dipergunakan dengan bentuk hipotesis deskriptif. Terdapat empat hipotesis deskriptif yang perlu diuji dengan menggunakan alat tenik statistic parametris. Proses analsis akan dibantu dengan Program Tools pada kumputer yaitu SPSS. Versi 23.

Analisis ini digunakan untuk menguji pengaruh antara variabel independen (X) dengan variabel depende $(\mathrm{Y})$, perhitungan akan dibantu dengan tabel penolong untuk variabel independen dan variable dependen, kemudian dirangkumkan hasil pengujian dalam satu tabel Hipotesis deskreptif.. Untuk menjelaskan ditolak atau diterimanya hipotesis maka berlaku hipotesisi statistik sebagai berikut :

$$
\text { Ho : } \mu=\mathrm{o} \text { (tidak ada pengaruh). } \mathrm{Ha}: \mu \neq \mathrm{o} \text { (ada pengaruh) }
$$

Berikut adalah hasil dari pengujian hepotesis dari variabel penelitian melalui data yang telah diolah atas serangkaian penelitian yang telah dilakukan : 
Uji Signifikan

\begin{tabular}{|c|c|c|c|c|c|c|}
\hline \multicolumn{7}{|c|}{ Tabel 7. Coefficients ${ }^{a}$} \\
\hline & \multirow[t]{2}{*}{ Model } & \multicolumn{2}{|c|}{$\begin{array}{c}\text { Unstandardized } \\
\text { Coefficients }\end{array}$} & \multirow{2}{*}{$\begin{array}{c}\begin{array}{c}\text { Standardized } \\
\text { Coefficients }\end{array} \\
\text { Beta }\end{array}$} & \multirow[b]{2}{*}{$\mathrm{T}$} & \multirow[b]{2}{*}{ Sig. } \\
\hline & & B & Std. Error & & & \\
\hline \multirow[t]{2}{*}{1} & (Constant) & 22.419 & 1.821 & & $\begin{array}{r}12.31 \\
4\end{array}$ & .000 \\
\hline & $\begin{array}{l}\text { X. kebijakan } \\
\text { pasca bayar }\end{array}$ & .217 & .087 & .337 & 2.480 & .017 \\
\hline
\end{tabular}

Koefesien regresi yang ditemukan sebesar 0.017 , dan nilai signifikan $Y$ lebih kecil dari $\alpha(0,05)$, yang artinya termasuk kategori pengaruh sangat signifikan maka secara statistik Ho di tolak dan sebaliknya Ha diterima. Dengan demikian maha hipotesisi tentang: "Diduga terdapat pengaruh Kebijakan Pasca Bayar terhadap piutang tak tertagi pada PT.PPILN Sulawesi Tenggara”, di terima.

Uji Koefisien determinasi (R Square)

\begin{tabular}{lcccr}
\hline \multicolumn{5}{c}{ Tabel 8. Model Summary } \\
\hline Model & $\mathrm{R}$ & R Square & $\begin{array}{c}\text { Adjusted R } \\
\text { Square }\end{array}$ & $\begin{array}{l}\text { Std. Error of } \\
\text { the Estimate }\end{array}$ \\
\hline $\begin{array}{l}\text { 1. kebijakan pasca } \\
\text { bayar }\end{array}$ & $.337^{\mathrm{a}}$ & .114 & .095 & 2.60944 \\
\hline a. Predictors: (Constant), $\mathrm{X}$ & b. Dependent Variable: $\mathrm{Y}$ & \\
\hline
\end{tabular}

Berdasarkan output model summary di atas, terlihat bahwa nilai $\mathrm{R}$ square sebesar 0,114 , yang artinya variable $Y$ (piutang tak tertagi) dipengaruhi sebesar $11,4 \%$ oleh variable $X$ (kebijakan pasca bayar), sedangkan selebihnya $88,6 \%$ di pengaruhi oleh variable lain yang belum dimasukkan dalam penelitian ini.

Hipotesis Kebijakan Pasca Bayar

Hasil pengolahan data yang terangkum pada tabel-tabel diatas selanjutnya dapat di bahas untuk mengetahui pengaruh antara variabel independen terhadap variabel dependen, yang kemudian akan dihubungkan dengan teori ataupun hipotesis yang disusun, penelitian yang relefan serta deskrepsi emperis di lapangan.

Rekap tabel uji hipotesis diatas menunjukan pengaruh antara Kebijakan Pasca Bayar Biaya Pemeriksaan Instelasi Listrik Tegangan Rendah (X) Terhadap Piutang Usaha Tak Tertagi. ditemukan sangat signifikan. Koefesien regresi yang ditemukan sebesar 0.017 , termasuk kategori pengaruh signifikan yang sangat kuat. Hal ini menunjukan $\mathrm{H} 1$ diterima dan Ho. ditolak, dan didukung nilai koefesien beta $(B=0.217)$ yang positif pada 
tabel di atas. Ini berarti Kebijakan Pasca Bayar Biaya Pemeriksaan Instelasi Listrik Tegangan Rendah (X) Terhadap Piutang Usaha Tak Tertagi. kesimpulan ini dapat digeneralisasikan ke populasi dimana sampel berada.

Rumusan hipotesi dalam penelitian ini sebagai berikut: Diduga terdapat pengaruh Kebijakan Pasca Bayar terhadap piutang tak tertagi pada PT.PPILN Sulawesi Tenggara. Temuan yang mendukung Hipotesis $X$ sejalan dengan teori yang dikemukakan Abdul Halim, 2002, kredit macet atau piutang tak tertagih dapat disebabkan oleh beberapa faktor yakni: Faktor Internal, yaitu faktor-faktor yang berasal dari pihak kreditur. dan Faktor Eksternal, yaitu faktor-faktor yang berasal dari pihak debitur. Faktor internal dimaksud antara lain adalah kebijakan penjualan kredit sebagai suatu strategi pemasaran yang di tempuh dalam dalam rangka peningkatan volume penjualan suatu produk, baik produk barang maupun pelayanan jasa. Hal ini sejalan dengan teori yang dikemukakan oleh Suharyadi dkk. 2007 bahwa strategi pemasaran (marketing strategy) adalah suatu cara yang digunakan untuk membantu kita membuat dan mejual barang dan jasa yang sesuai dengan kondisi perusahaan dan pasar target atau selerah konsumen yang dituju.

Hasi pembahasan dan temuan hipotesis yang diterima di atas dapat sejajarkan dengan penelitian yang relevan yakni penelitian penelitian terdahulu yang dijadikan sebagai rujukan dalam penelitian ini. Hasil ini sejalan atau dengan kata lain penelitian mendukung hasil penelitian dari saudari Arsyina Lutfi Arrum Sari. 2015. Hasil penelitiannya menunjukkan, faktor-faktor penyebab piutang tak tertagih ada 2 yaitu faktor intern dan faktor ekstern. Untuk faktor intern sendiridi dipengaruhi oleh pihak Pelabuhan dan pengguna jasa, sedangkan faktor ekstern disebabkan oleh kondisi yang tidak pernah diharapkan oleh pihak manapun.

Secara emperis atas pengamatan realitas di lapangan, PT. PPILN Pusat telah menetapkan sistem pembayaran Biaya Pemeriksaan Instelasi liatrik, yakni harus dilakukan atau dilunasi sebelum dilakukan pemeriksaan instealsi di rumah rumah atau bangunan lain. Dengan kata lain harus membayar dulu kemudian intelasinya diperiksa selanjutnya diterbitkan sertifika like operasional atas instelasi tersebut, hal ini berlaku secara nasional. Akan tetapi pengurus PT.PPILN Wilayah Sulawesi Tenggara menempuh yang sebaliknya yaitu setelah pemeriksaan hingga penerbitan SLO, baru boleh dibayar Biaya Pemeriksaan. Hal inilah yang memicu timbulnya piutang tak tertagi, walaupun prosentase piutang tertagi lebih tinggi daripada piutang tak tertagi. Kondisi ini berlangsung dari tahun pertama berdiri hingga saat penelitian ini dilakukan.

Determinasi Variabel Kebijakan Pasca Bayar terhadap piutang tak tertagih

Nilai R square yang terdapat pada tabel Model Summary diatas sebesar 0,114, yang artinya variable piutang tak tertagi dipengaruhi sebesar $11,4 \%$ oleh variable kebijakan pasca bayar, sedangkan selebihnya $88,6 \%$ di pengaruhi oleh variable lain yang belum dimasukkan dalam penelitian ini. Temuan ini sejalan pula dengan teori teori diatas terutama teori yang dikemukakan oleh Abdul Halim, 2002. Bahwa piutang tak tertagi dipengaruhi oleh berbagai faktor yang di klasifikasikan kedalam faktor internal dan faktor eksternal, dimana kebijakan hanyalah satu bagian kecil daripada faktor internal. Walaupun kebijakan penjualan kredit merupakan titik awal dari pada 
munculnya piutang tak tertagih itu, namun upayah meminimalisir piutang tak tertagi dari sisi internal akan lebih lanjut dilaksanakan secara teknis melalui metode metode akuntansi yang terstandar seperti pengendalian piutang, penagihan, dan upaya upaya lain. Semetara faktor eksternal lebih banyak ditentukan oleh keadaan para debetur atau orang orang yang berhutang serta kondisi fasmayor lainnya.

\section{KESIMPULAN}

Berangkat dari suatu konstruksi atas gep venomena dan permasalahan serta hipotesis yang dibangun,kemudian dilanjutkan dengan koidah koidah statistik serta interprestasi berdasarkan teori, research yang relevan dan pengamatan imperis secara saksama maka satu kesimpulan tunggal yang dapat ditarik dari penelitian ini adalah : Kebijakan Pasca Bayar Berpengaruh Secara Sangat Signifikan Terhadap Piutang Tak Tertagi di PT. PPILN Wilayah Sulawesi Tenggara. Kepada pengelolah perusahaan pada umumnya dan khususnya PT. PPILN Wilayah Sulawesi Tenggara, dalam mengelolah piutang piutangnya hendaknya mempertimbagkan secara matang kebijakan yang diambil terkait strategi penjualan kredit/pasca bayar, selalu memperhatikan aturan aturan yang disepakati antar pihak, baik aturan hutang piutang antar kreditur dan debitur maupun aturan korporasi yang berlaku. Oleh karena, fokus kajian penelitian ini hanya pada kebijakan pasca bayar yang menyebabkan piutang tak tertagi saja, maka Peluang kajian bagi peneliti peneliti yang akan datang adalah faktor faktor teknis baik secara internal atupun eksternal yang menyebabkan terjadinya piutang tak tertagi pada suatu intitas bisnis tertentu.

\section{UCAPAN TERIMA KASIH}

Penulis mengucapkan terima kasih kepada Lembaga Penelitian dan Pengabdian Kepada Masyarakat (LPPM), Universitas Muhammadiyah Kendari yang telah memberikan dukungan finansial dalam penelitian ini.

\section{DAFTAR PUSTAKA}

Abdul Halim, 2002. Akuntansi Sektor Publik Keuangan Daerah, Edisi1. Jakarta: Salemba Empat.

Arsyina Lutfi Arrum Sari, 2015. Analisis Faktor-Faktor Penyebab Piutang TakTertagih Pada PT.PELINDO III (Persero) Cabang Tanjung Emas Semarang. Skripsi: Universitas Negeri Semarang.

Devianti, 2012. Tinjauan Atas Analisis Piutang Usaha Pada Toyota Sales Operation (Auto 2000) Cabang Cibiru Bandung, Jurnal Universitas Widyatama.

Donald E.Kieso And Jerry J, 2004. Weygant, Akuntansi Intermediate, edisi 7, jilid I, Terj. Herman Wibowo. Jakarta: Erlangga.

Iryani, 2016. Analisis Pengelolaan Piutang Usaha Robin Cell.Jurnal, STIE Wira Bhakti Makassar.

Murni, 2009. Analisis Pemberian Kredit Dalam Menunjang Perkembangan Industri Kecil di Kota Makassar. Jurnal Ekonomi BALANCE. Fakultas Ekonomi Universitas Muhammadiyah Makassar. 
Mikky Fariana, Elfreda A Lau dan Adi Suros, 2012. Pengendalian Piutang Dagang Pada PT.Kokoh Inti Arebama Cabang Samarinda. Jurnal Universitas 17 Agustus 45 Samarinda.

Muhammad Indra Lukman Hakim 2016, Penanganan Piutang Tak Tertagih Dalam Perspektif Ekonomi Islam (Studi Kasus di Toko Bangunan Sumber Makmur Pegandon Kendal). Skripsi: Universitas IslamNegeri Walisongo Semarang.

Neneng Salmiah, Satria Tri Nanda, 2016. Analisis Penilaian Kredit Pada BPR Indo Mitra Mega Kapital dan BPR Payung Negeri Bestari di Kota Pekanbaru. Jurnal Universitas Lancang Kuning.

Rahmini Hadi, 2011. Manajemen Keuangan, STAIN Press Purwokerto.

Ricky W. Grifin dan Ronald, 2006. Bisnis, edisi Kedelapan, Penerbit PT.Gelora Aksara Pratama.

Rudianto, 2012. Pengantar Akuntansi. Jakarta: Erlangga.

Sugiyono, 2008. Metode Penelitian Bisnis. Penerbit Alfabet.

Sugiyono, 2010. Statistik Untuk Penelitian. Penerbit Alfabet.

Suryadi dkk, 2007. Kewirausahaan Membangun Usaha Sukses Sejak Usia Muda, Penerbit Salemba Empat. 